\title{
36. STRATIGRAPHY AND STRUCTURES OF THE MIDDLE AMERICA TRENCH: DEEP SEA DRILLING PROJECT LEG 67 TRANSECT OFF GUATEMALA ${ }^{1}$
}

\author{
William T. Coulbourn, Geological Research Division, Scripps Institution of Oceanography, University of California, \\ San Diego, La Jolla, California
}

\begin{abstract}
The eight holes drilled at Sites 499 and 500 in the axis of the Middle America Trench are the first to recover the complete sedimentary section of an active trench. These holes demonstrate extension of the subducting Cocos Plate and its sedimentary overburden, even at the edge of the Guatemalan margin. A depression within the turbidites filling the Trench is probably a result of warping of those beds by differential movements of the underlying structures, and not the result of erosion by turbidity flows along the bottom of the Trench. Patterns of reflectors on seismic profiles match the well-derived cross section but taken alone would not reveal the wealth of detail and perhaps not even the major structures underlying the turbidite fill. Drilling and geophysical data at Sites 499 and 500 suggest that rather than becoming incorporated into the lowermost Guatemalan margin, axial turbidites are passively buried beneath slope sediments.
\end{abstract}

\section{INTRODUCTION}

During Leg 67 of the Deep Sea Drilling Project eight holes were drilled in the axis of the Middle America Trench seaward of the coast of Guatemala (Fig. 1). This sampling pattern was not planned prior to sailing, but because the recovery of clathrates forced reassessment of drilling plans for the Guatemalan margin, the Trench axis holes were drilled as a matter of expediency. Hourto-hour contingency planning dictated early abandonment of some holes and produced an irregular pattern of coverage (Fig. 2). Trench-axis drilling was not the first priority of Leg 67 , nor is it likely to be of first-order importance in upcoming drilling expeditions, therefore, so dense a coverage of this setting will probably not occur in the near future. Previous Challenger expeditions drilled Holes 127, 127B, and 128 in the Hellenic Trench, Hole 174 off the coast of Oregon, Hole 180 in the Aleutian Trench, and Holes 486 and 486A in the Middle America Trench (Ryan, Hsü et al., 1973; Kulm, von Huene, et al., 1973b; Watkins, Moore, et al., 1982). None of those wells recovered a complete lithologic section from the turbidite wedge, through the sedimentary overburden of the subducting plate, down to the basalt of the plate itself. Sites 499 and 500 provide the first complete record of the sedimentary section of an active trench and will therefore, in all likelihood, remain a unique base for the interpretation of structures within the Middle America Trench and for trenches within other subduction zones of the world.

\section{COMPARISON OF THE LEG 67 STUDY AREA WITH OTHER TRENCHES}

Earthquake foci (Benioff, 1954; Molnar and Sykes, 1969), plate motion (Jordan, 1975; Minster and Jordan, 1978), and the geometrical framework of crustal plates (Morgan, 1968) indicate that the Middle America Trench

\footnotetext{
${ }^{1}$ Aubouin, J., von Huene, R., et al., Init, Repts. DSDP, 67: Washington (U.S. Gov!. Printing Office).
}

is the product of convergence of the Cocos and Caribbean plates. The combination of outer swell, offsets, and earthquake focal mechanisms for world subduction zones has led to the concept that the subducting plate behaves as an elastic beam with a load applied at one end (Isacks et al., 1968; Hanks, 1971; Caldwell et al., 1976). Paradoxically, therefore, plate convergence produces extensional stress in the upper surface and in the subducted portion of the Cocos Plate (Dean and Drake, 1978) as the Cocos Plate sinks into the asthenosphere under the influence of gravity (Isacks and Molnar, 1969).

Extension is evident in the series of stepped offsets and in the horst that form the topography seaward of the axial deep of the Middle America Trench (Fig. 3). In Profile $\mathrm{AA}^{\prime}$, reflectors from pelagic sediments mantling basement are truncated, as they are, for example, west of the Manila and Peru-Chile trenches and north of the Puerto Rico Trench (Ludwig et al., 1967; Coulbourn and Moberly, 1977; Shepherd and Moberly, 1981; Ewing et al., 1965). Direct observation of similar outcrops from submersibles lowered into the Izu-Ogasawara (Bonin) Trench indicate normal faulting (Bellaiche, 1967; 1980).

Seismic-reflection profiles suggest that subducting oceanic plates and their sedimentary overburden are passively buried beneath wedges of sediment filling the trench axis. Profiles of the Aleutian Trench (fig. 2: profiles 2 and 4, von Huene, 1972; fig. 2, Piper et al., 1973), across the Peru and Middle America trenches (figs. 5 and 9, Shepherd and Moberly, 1981; fig. 6, Ross and Shor, 1965; fig. 5, Shipley, 1982), and seaward of Barbados (figs. 2 and 3, Chase and Bunce, 1969) are a few examples of this burial. Faults and steep slopes conceal the turbidite-pelagic sediment onlap in Profile AA $^{\prime}$ (Fig. 3) and in multichannel profile GUA-13 (Fig. 4), but it probably dips landward from the seaward limit of the turbidite fill. Cores from the Middle America Trench and various other trench axes have recovered graded beds and displaced shallow-water benthic foraminifers and bivalves, brackish-water diatoms, organic debris, 


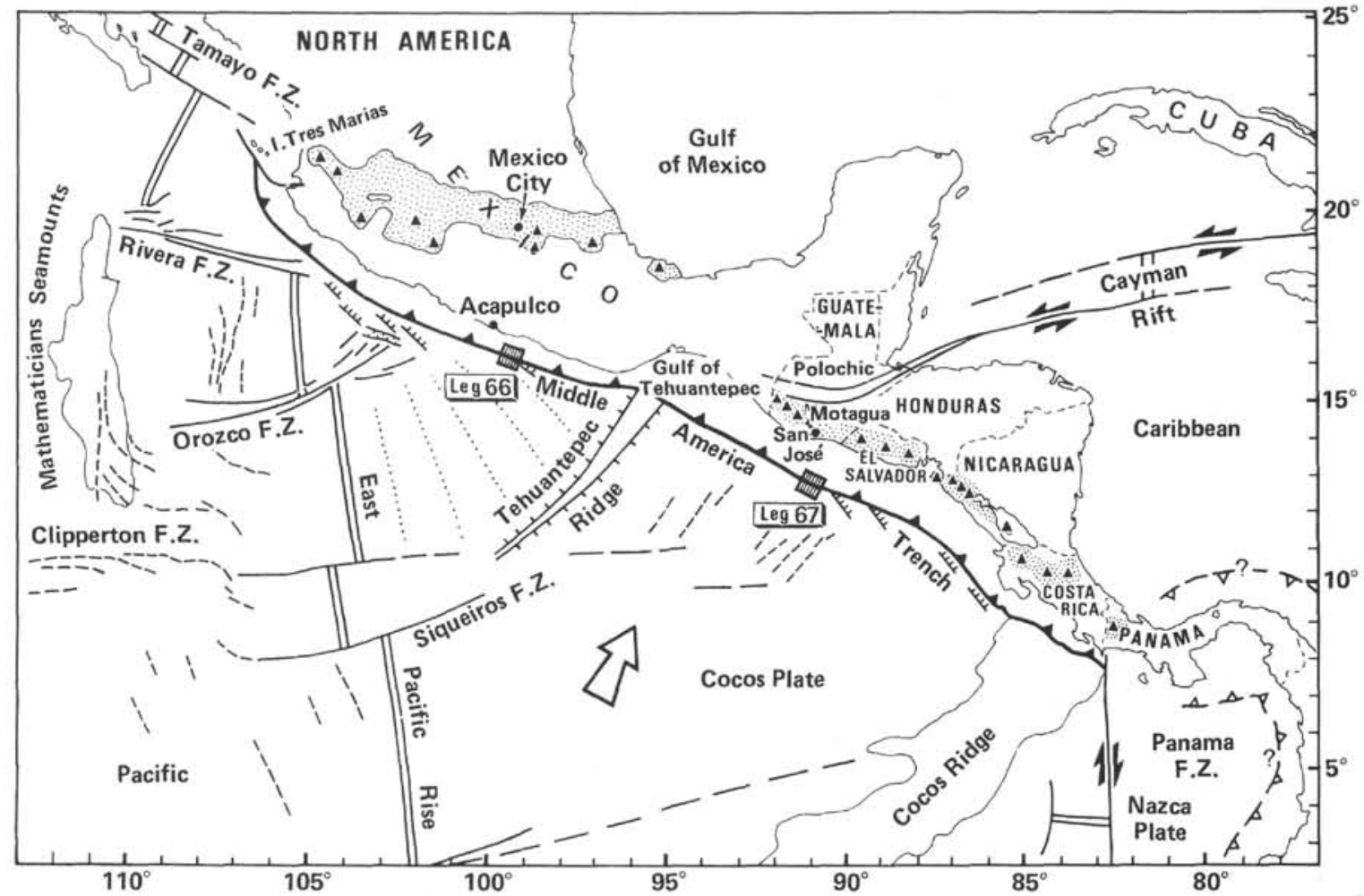

Figure 1. Location of the DSDP Leg 67 study area.

wood, and mineral assemblages indicating deposition by turbidity flows originating high on the landward slope (Fisher, 1961; Connolly and Ewing, 1967; Ross, 1971; Prince, et al., 1974; Coulbourn, 1980; Resig, 1981; Jousé et al., this volume; and Thompson, this volume). Most seismic-reflection profiles across trenches show the axial turbidites as strong, subhorizontal reflectors with little or no indication of folding (for examples see Scholl et al., 1968; Chase and Bunce, 1969; Coulbourn and Moberly, 1977; Moore and Curray, 1981) and, as indicated in Profile $\mathrm{AA}^{\prime}$, these abut the toe of the continental margin along a tectonic front (Lister, 1969; Montecchi, 1976). On the basis of the first set of seismic profiles across the Middle America Trench, Ross and Shor (1965) concluded, "None of these profiles show evidence of the accumulation of contorted sediments at the foot of the continental slope required by Dietz's (1961) theory of seafloor spreading." Indeed, the absence of compressive features provoked some of the first discussions of the association of tensile stresses and subduction (Elsasser, 1968; von Huene et al., 1968a and 1968b; Seyfert, 1969).

\section{STRATIGRAPHY OF SITES 499 AND 500}

The Middle America Trench axis is about $5 \mathrm{~km}$ wide at the Leg 67 transect; drilling at the eight holes of Sites 499 and 500 investigated the sedimentation process, the lithology, and the structure of the landward half of the axial basin (Fig. 2). The Leg 67 sedimentology summary includes details of the provenance, deposition, and diagenesis of these deposits (Coulbourn et al., this volume); the spatial relation of the lithologic units is the subject of the following discussion (Fig. 5).
The complete section drilled in Holes 499 and 499B resembles the hemipelagic mud-abyssal clay-chalk-basalt sequence drilled at the oceanic reference Site 495 . Important differences are the lack of a turbidite capping at Site 495 and the absence of a distinctive layer of red brown abyssal clays at Hole 499. Dark red mottles do occur, however, in Section 499-23-1 and these may be the reworked traces of an abyssal clay horizon. The foraminifer-nannofossil ooze-hemipelagic clay contact was recovered intact at Section 499-23-1. Evidently, the history of sedimentation at Site 499 differed from that at Site 495 . The absence of abyssal clays at Site 499 suggests arrival of hemipelagic sediments at the site's paleolocation near the time of its subsidence beneath the calcite compensation depth (CCD). That arrival interrupted deposition of the normal sedimentary sequence predicted by a Plate Stratigraphy model (Berger and Winterer, 1974). Those events are not directly related to tectonics within the Trench. In contrast, the foraminifer-nannofossil ooze-turbidite contact in Section 50010-2 probably arises from faulting and exposure of the section as it moved across the seaward flank of the Trench. A modern analog for Hole 500 is an exposure of middle Eocene pelagic carbonates on the seaward flank of the Peru-Chile Trench, well below the CCD (Coulbourn and Resig, 1979). Location near or on the crest of a horst would offer ample opportunity for bottom currents to strip away the hemipelagic mud cover. Basalt was encountered at an unexpectedly wide range of subbottom depths - a maximum of 275 meters at Hole 499B and a minimum of 115 meters at Hole 500A. Because the foraminifer-nannofossil ooze is missing, structural control best explains the hemipelagic mud-basalt con- 


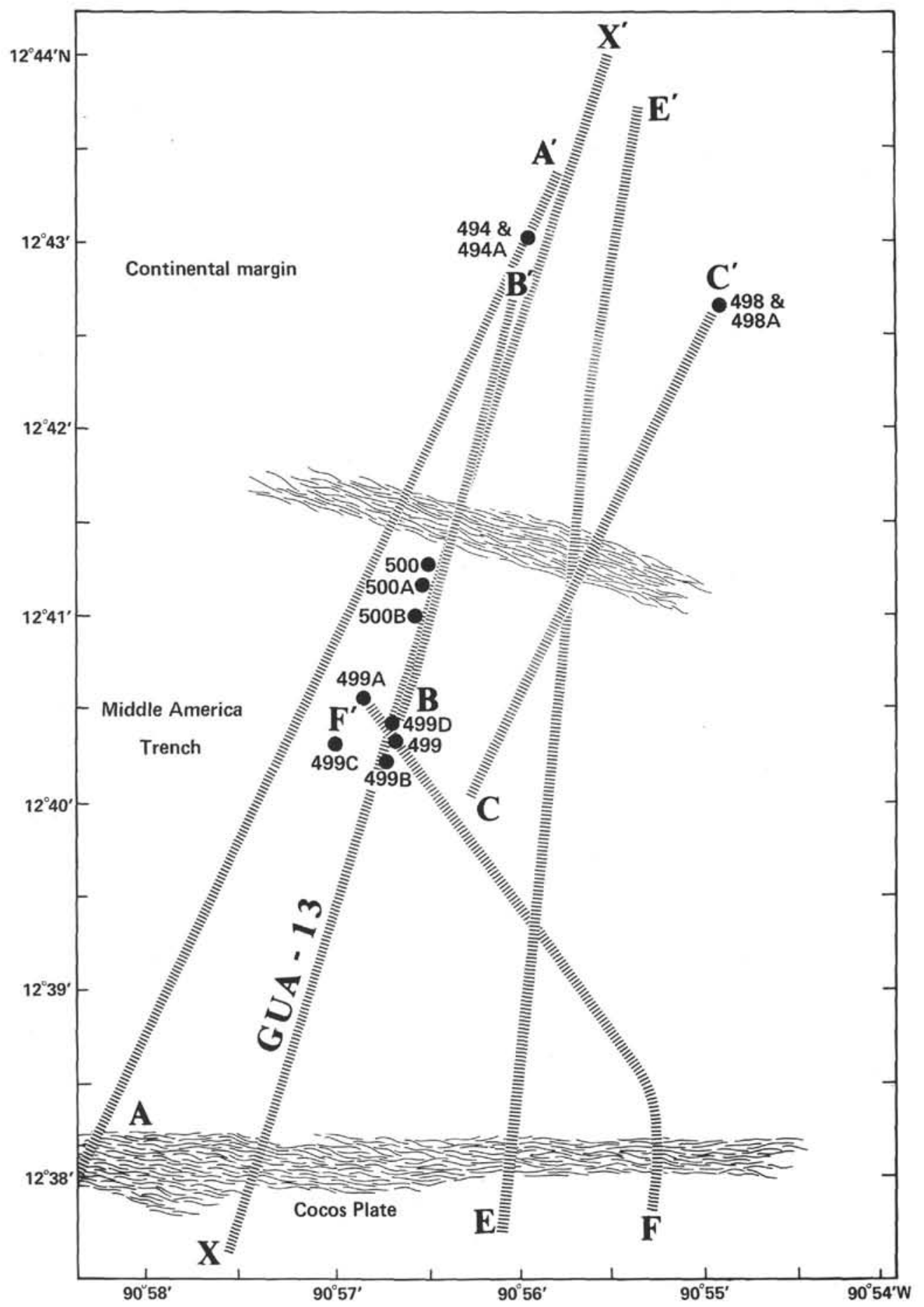

Figure 2. Location of drill holes and seismic-reflection profiles of the Middle America Trench axis. (Wavy pattern marks the approximate boundary of the Trench axis. Letters and striped patterns locate reflection profiles referred to in the text.)

tacts at Sections 499D-1-1, 500B-3-1, and 500A-2,CC. Two limestone clasts were retrieved in Hole 500A.

Features that might indicate compression are absent, even at Hole 500, located at the landward fringe of the Trench axis. Two small reverse faults were attributed to differential compaction (Dengo, this volume); moreover, neither folds, stratigraphic reversals, nor repetitions of lithologic units were observed in the cores from these holes.
The interpretation drawn in Figure 6 shows a basalt ridge and its overburden of chalk and hemipelagic sediment buried beneath turbidites of the Trench axis between Holes 500B and 500. On the basis of available seismic-reflection profiles, the presence of a buried ridge was not anticipated prior to drilling. The cross section is only one of many possibilities; tilted beds are not required, and some of the fault contacts could be depositional contacts. Sub-bottom structure probably controls 


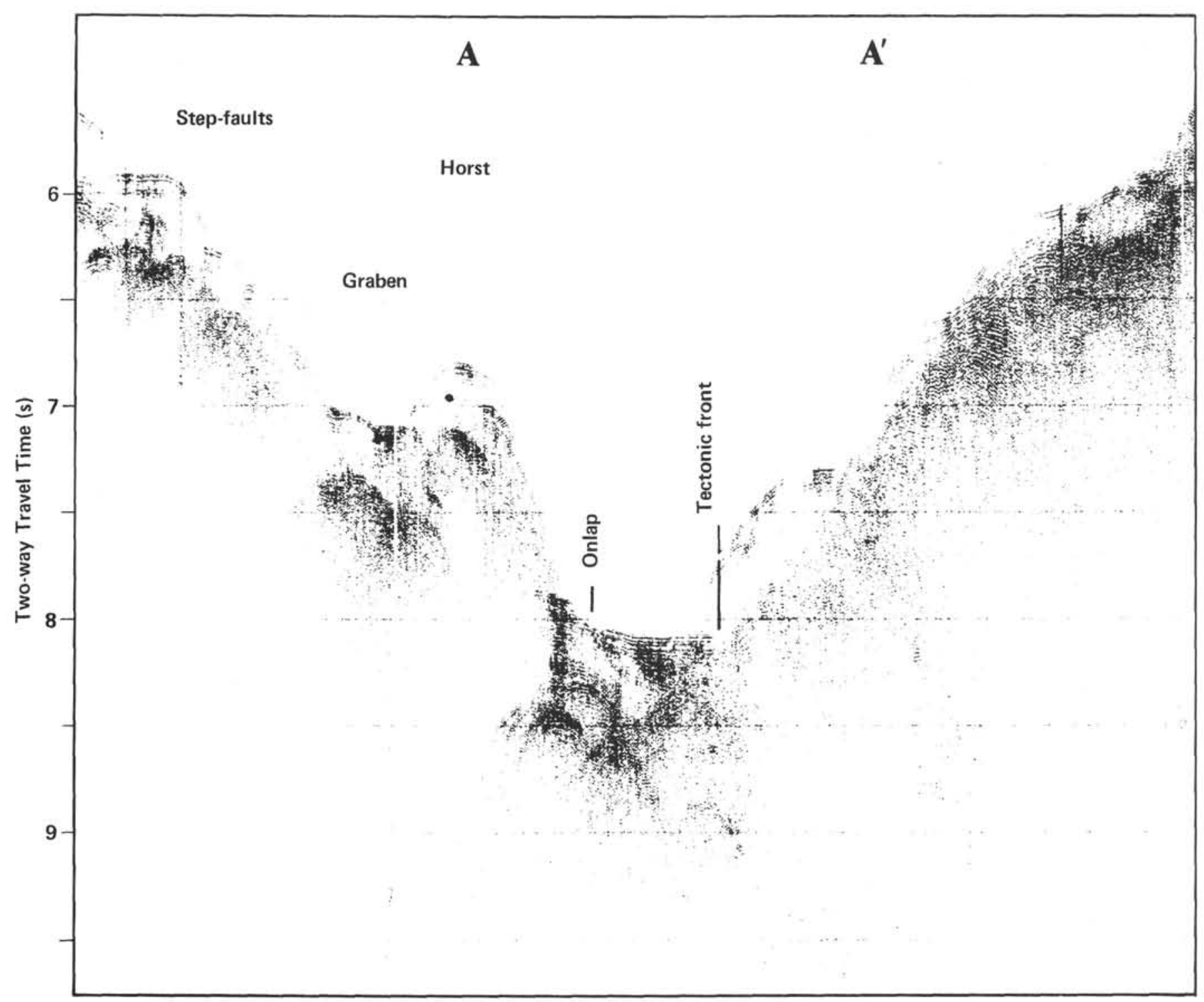

Figure 3. Seismic-reflection profile $\mathrm{AA}^{\prime}$. (Frequency bandwidth is $40 \mathrm{~Hz}-160 \mathrm{~Hz}$; profile location is shown in Fig. 2.)

surface topography. The uniformity of facies reported for Site 499 turbidites (von Huene et al., 1980) indicates that the depression at Hole 499A is probably not erosional but instead a gentle warp reflecting the underlying fault-controlled structure. If we assume superposition and lateral continuity for the deposition of the carbonates and the hemipelagic mud units, the omission of strata (carbonates at Holes 499D, 500B, and 500A, and hemipelagic mud at Hole 500) and the relatively smooth surface topography require that gravity faulting is occurring as turbidites are accumulating. The lithology and spatial arrangement of these drill holes require extension even at the edge of the landward slope of the Trench. In contrast, the Trench Slope Model, a generally accepted scheme for the structure of convergent margins, depicts reverse or overthrust faults within the Trench axis (Seely et al., 1974). Those compressive features would produce thickening by repetition of the stratigraphic section, not the observed abbreviation.

\section{COMPARISON OF SEISMIC PROFILES WITH DRILL-CONTROLLED CROSS SECTION}

In most single- and multichannel seismic profiles great water depths, high vertical exaggeration, and strong diffractions camouflage structures beneath the turbidites ponded in trench axes. The eight holes drilled at Sites 499 and 500 therefore provide unique well-control for seismic-reflection profiles of this structurally complex setting. In the following discussion hole locations are projected orthogonally or along strike onto the plane of the profile, and tracings are shown above some of the seismic records. Drill penetration is approximated very crudely, assuming a velocity of $1.5 \mathrm{~km} / \mathrm{s}$ for the lithologic column. The velocity structure of the sediments penetrated is expected to exceed this value; therefore the penetrations indicated are minimum.

For the Middle America Trench axis water depth of $6000+$ meters, $3.5 \mathrm{kHz}$ profiles record reflections from 


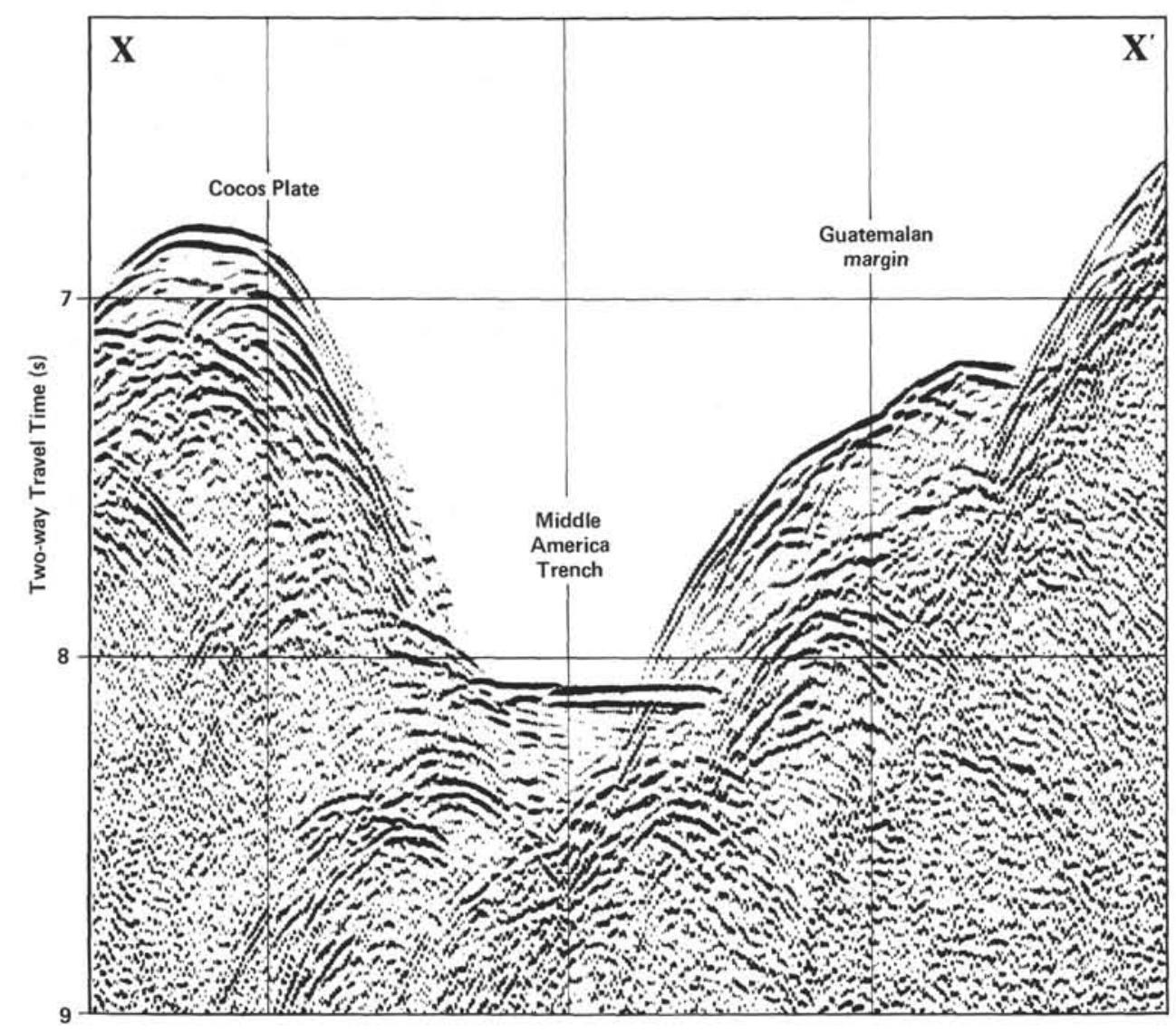

Figure 4. Multichannel seismic-reflection profile GUA-13. (For location see Fig. 2 [Profile X-X'] and for details of processing see Ladd et al. [this volume].)

no more than 60 meters sub-bottom depth, revealing the form of the turbidite wedge (Figs. 7 and 8 ). For profile segment $E^{\prime} E$ the turbidites drape subsurface structure and, as discussed earlier, their warping and variable thickness is probably related to the form and faulting of the Cocos Plate and its sedimentary overburden (compare Figs. 6 and 7). Hole 500 is located beneath a reflection hyperbola originating from the landward slope.

Profile FF' was recorded as the ship approached Site 499 and slowed for drilling (Fig. 8). It crosses the Trench axis obliquely, paralleling the strike of the axial ridge. Turbidites thicken toward the northwest, reflecting the plunge of underlying structure.

As expected for the lower frequency, $40 \mathrm{~Hz}$ to $80 \mathrm{~Hz}$ bandwidth, sub-bottom penetration is enhanced at the expense of resolution of surface features. For water depths of $6000+$ meters found off the shore of Guatemala, energy returned from as much as 400 meters subbottom (Figs. 9, 10, 11). All three records show diffraction hyperbolas representing the edge of the Guatemalan margin. Holes 500 and $500 \mathrm{~A}$ plot beneath the limbs of these diffractions. These records and tracings also show a general relation between depth to basalt at Holes 499B, 499C, 499D, 500B, 500A and 500 and an apparent hyperbolic reflector beneath the horizontal reflectors from the Trench-filling turbidites. Perhaps this coincidence is chance, but in the case at hand that curved reflector coincides with basement. In Profile E'E, a series of poorly organized reflectors and bubble pulses represent the interval occupied by hemipelagic and calcareous sediments, and, with considerable vertical exaggeration and with some adjustments, the lithologic cross section of Figure 6 matches the tracing (Fig. 10). Without prior knowledge, however, considerable luck would be required to predict the geologic cross section from the seismic profile. For these great water depths, steep slopes, fault-controlled structures, and detailed features the multichannel profile offers little more than does the single-channel profile to aid structural interpretations (compare Figs. 4 and 6). Even with both profiles in hand prior to drilling, the presence of basalt at shallow levels at Site 500 came as a complete surprise. To a lucky observer, Profile $\mathrm{CC}^{\prime}$ might have hinted at the geologic structure eventually drilled (Fig. 11). In contrast to all the other profiles, a group of weak reflectors in Profile $\mathrm{CC}^{\prime}$ is superimposed on and above those from the axial turbidites. These are perhaps side echos marking the protrusion of the axial ridge above its cover of turbidites.

\section{DISCUSSION}

A general block diagram, constructed from preliminary results of a Seabeam survey (Aubouin et al., this volume), shows a three-dimensional framework of the Guatemalan transect (Fig. 12). An anastomosing network of normal faults arises from a combination of bending of the downgoing Cocos Plate during subduc- 


\section{S SW}

495-19-5

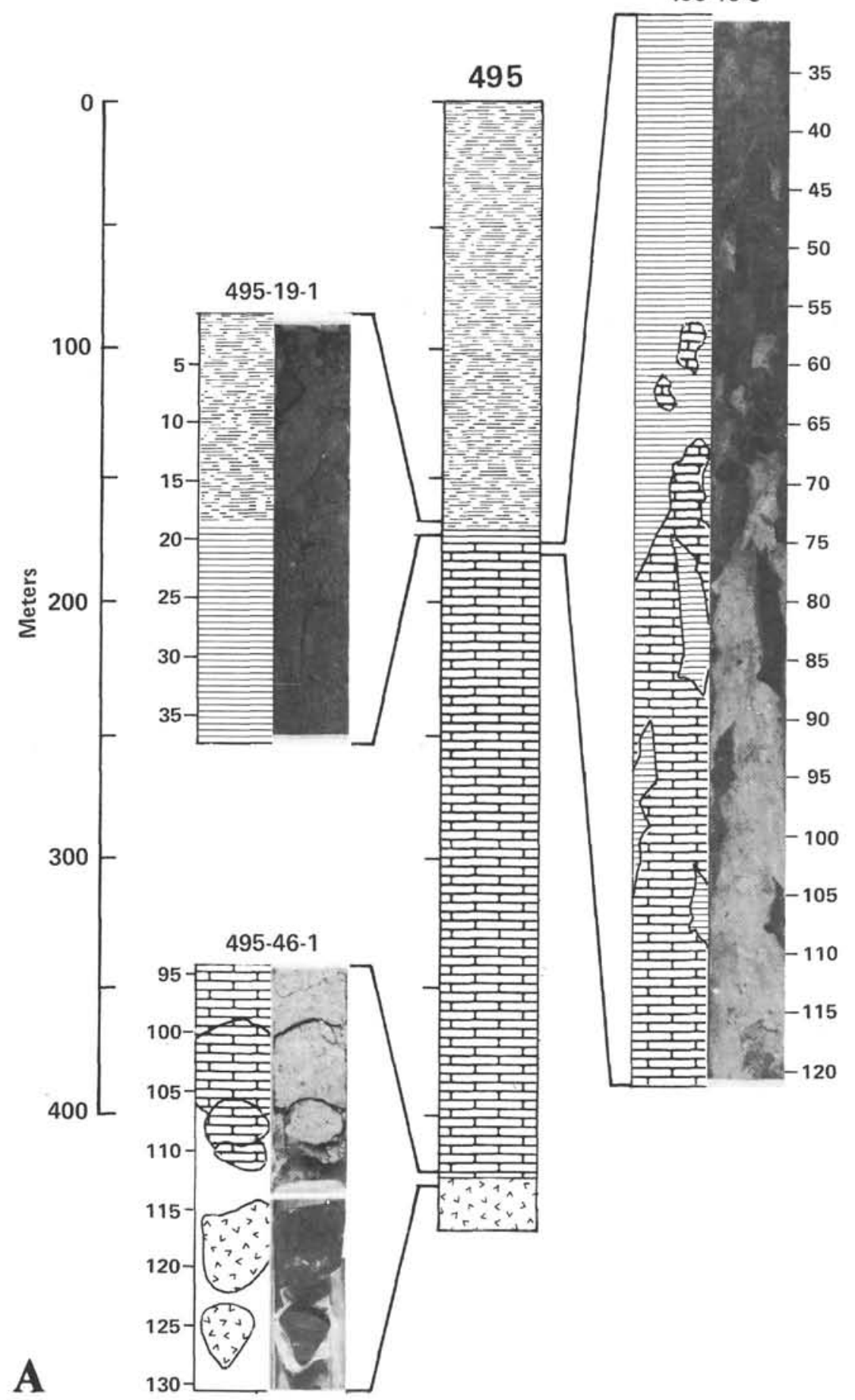

Figure 5. Major lithologic units and key contacts at Sites 495, 499, and 500. (General lithologic columns for each of the eight holes are arranged according to distance from shore [for more detailed descriptions, see respective site chapters, this volume]. Lithologic contacts are shown schematically and in the photographs beneath their respective site-core-section designations. Tie lines indicate the sub-bottom intervals shown in detail. A legend for patterns is shown in Fig. 12. Considerable drilling deformation occurred across the contacts in Sections 495-19-5 and 500-10-2. Only turbidites were recovered at Hole 499A and only basalt at Hole 499C.) 


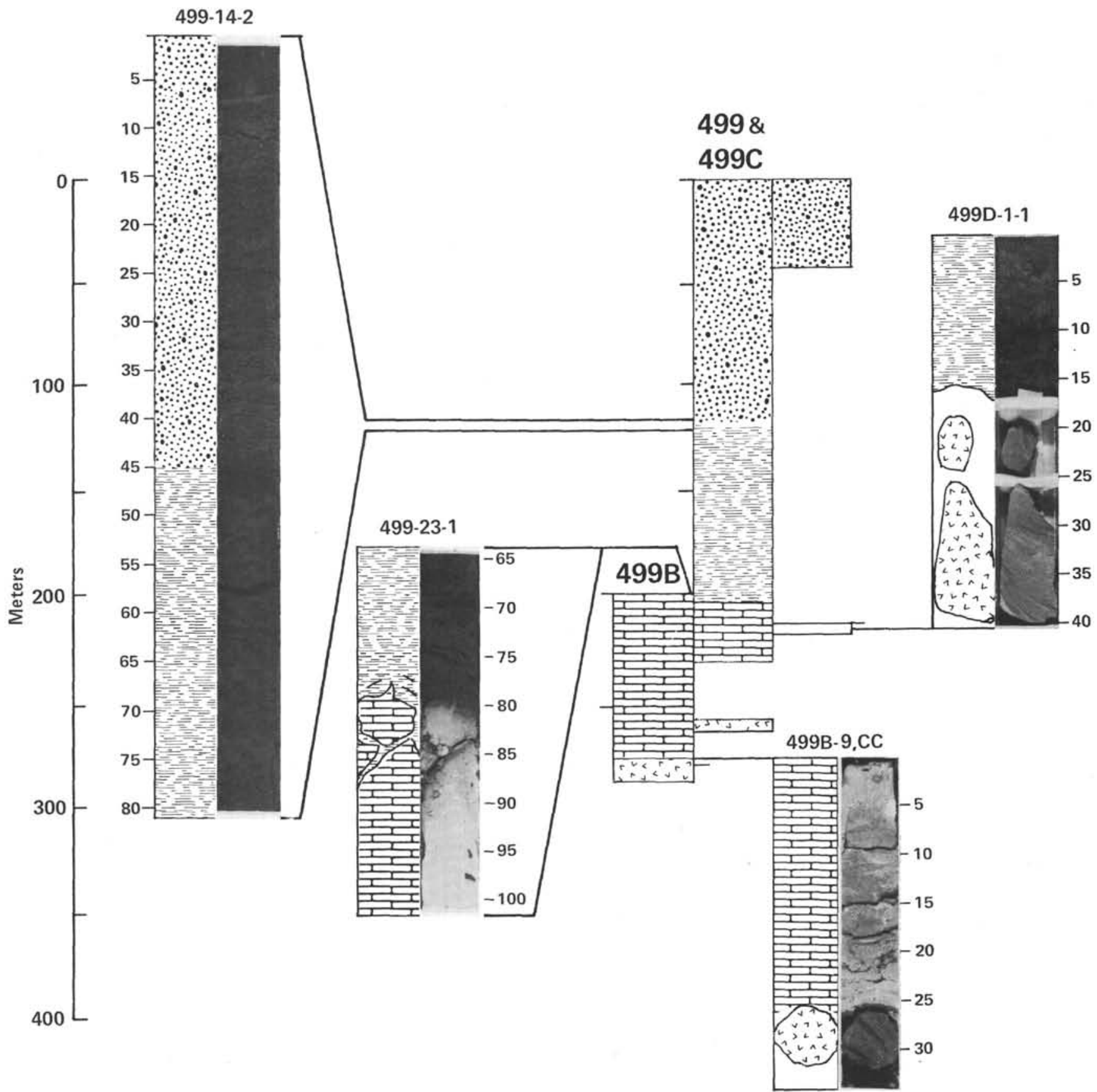

B

Figure 5. (Continued). 


\section{SSW}

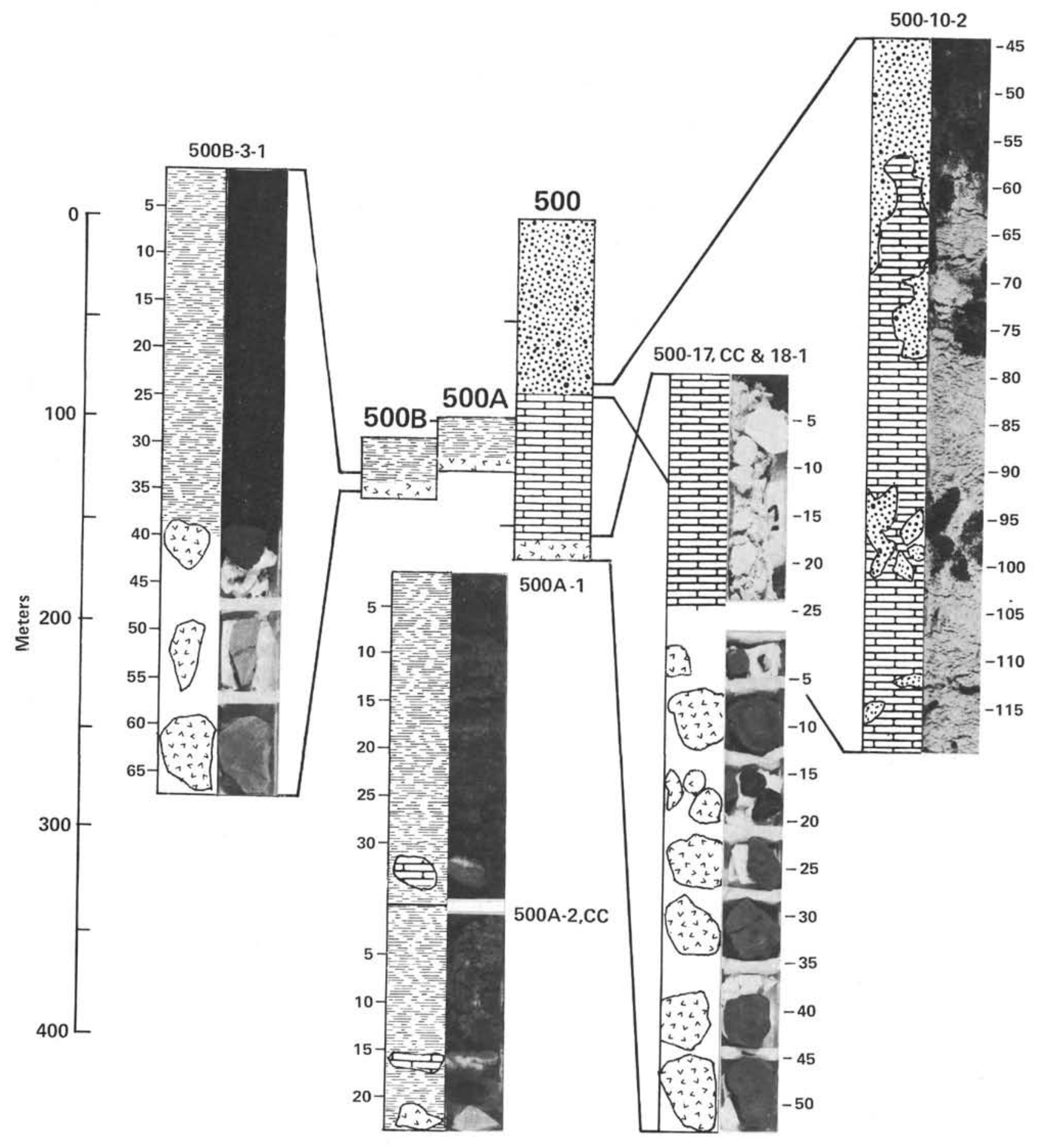

C

Figure 5. (Continued). 


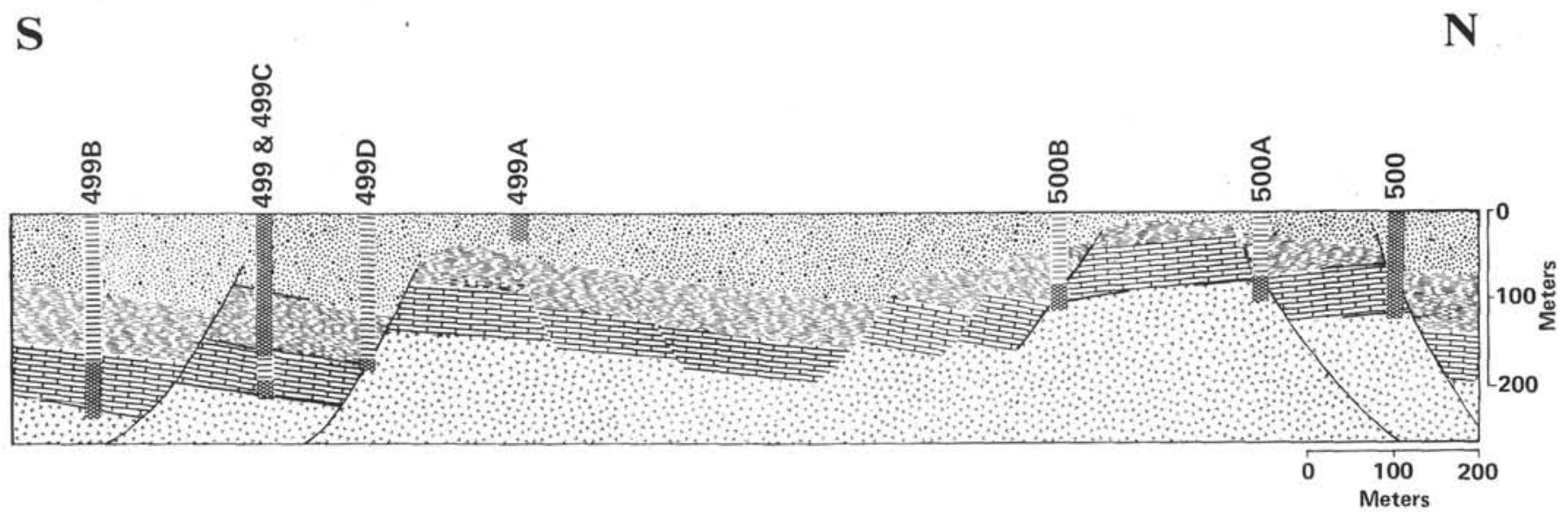

Figure 6. Geologic cross section of the Middle America Trench axis. (Control is based on the results of drilling eight holes and the projection of those results onto a north-south plane. Crisscross pattern represents intervals of continuous coring, and stripes of paired horizontal lines indicate washed intervals. Legend for lithologic patterns is shown in Fig. 12)

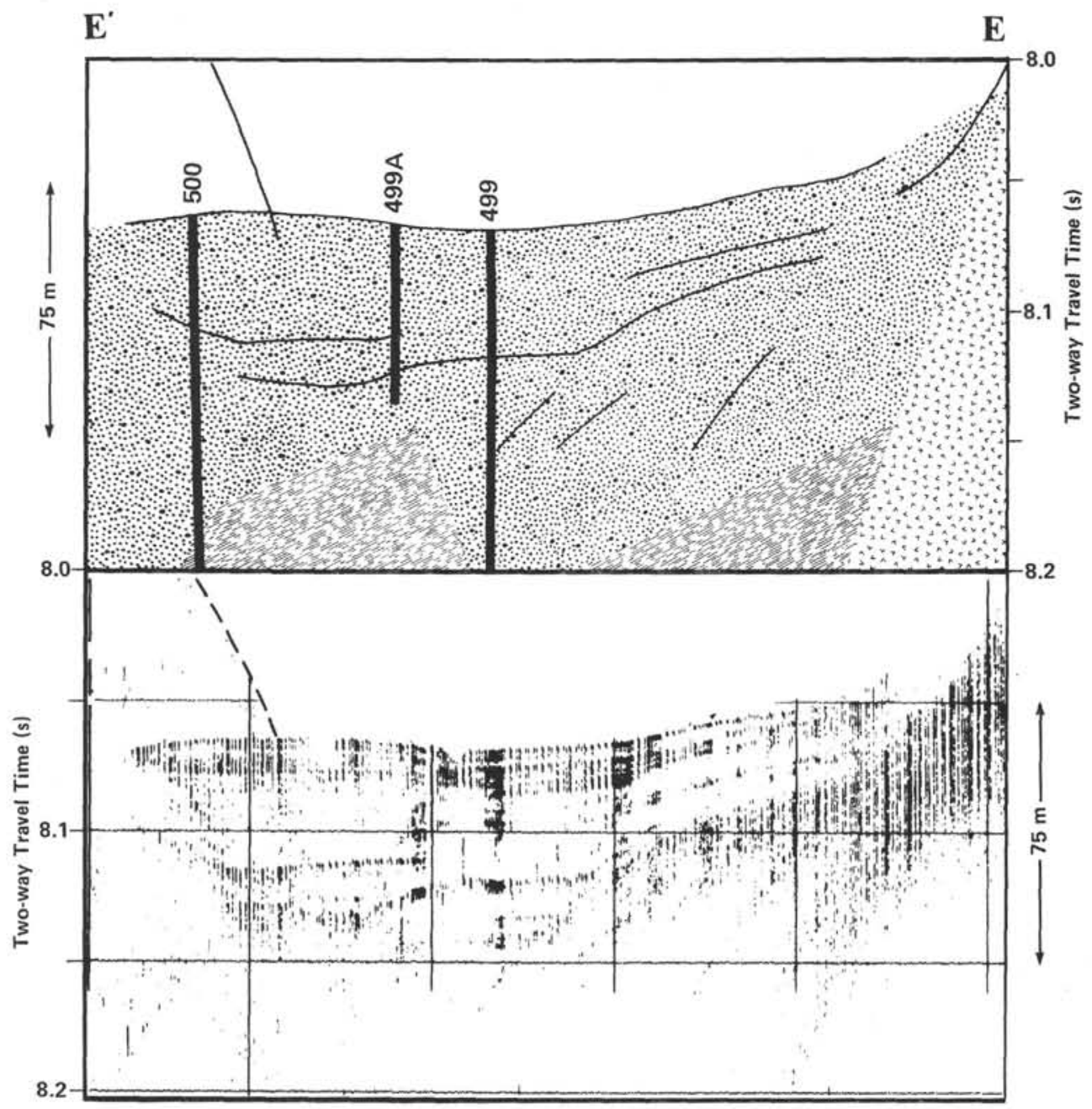

Figure 7. Segment of seismic-reflection profile $E^{\prime} E$ and its tracing. (Black vertical lines indicate the projection of continuously cored drill holes onto this profile. Patterns represent approximate bounds of lithologic units shown in Fig. 6. Dashed curve in lower portion represents position of reflection hyperbola too faint in original $3.5-\mathrm{kHz}$ record to reproduce in this figure [compare with Fig. 9]. See Fig. 2 for profile location.) 


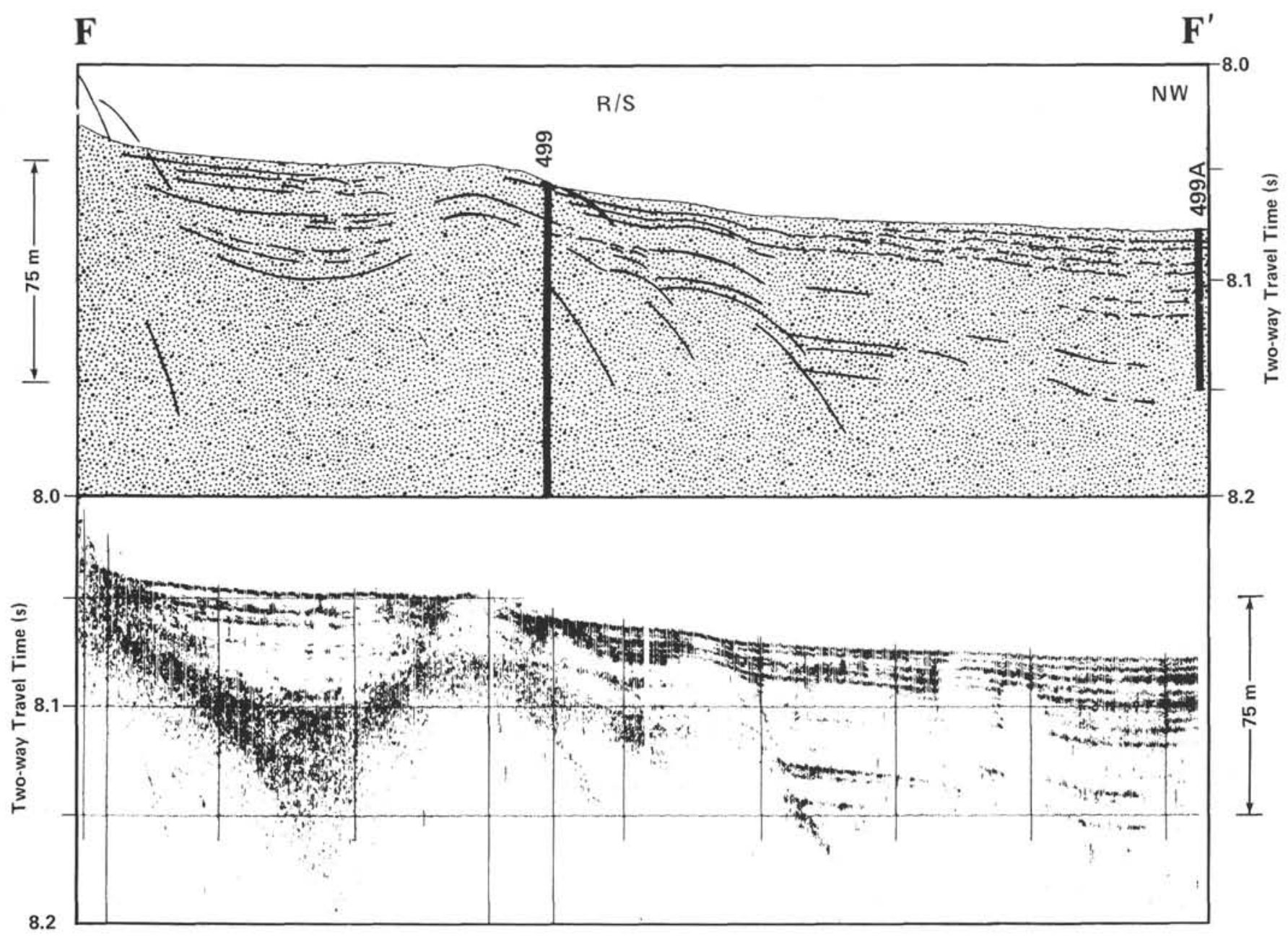

Figure 8. Seismic-reflection profile $\mathrm{FF}^{\prime}$ and its tracing. (Black vertical lines indicate the projection of continuously cored drill holes onto this profile. This 3.5-kHz record is oriented parallel to the ridge crossing the Middle America Trench axis [see Figs. 2 and 12]. Structures within the turbiditefill plunge toward the northwest, mimicking a similar attitude of the underlying structure. $\mathrm{R} / \mathrm{S}$ indicates reduced ship speed.)

tion and the reactivating of lines of weakness-the Cocos Plate tectonic fabric (after Rona et al., 1976) originally created at the East Pacific Rise crest. Coulbourn and Moberly (1977) and Honza (1980) described a similar pattern for the eastern edge of the Nazca Plate and the western edge of the Pacific Plate, respectively. Sufficiently dense track coverage will probably reveal this type of pattern seaward of other trenches. The fabric of the Cocos Plate parallels the alignment of the magnetic anomaly pattern (see fig. 7, Karig et al., 1978), and is also evident on Fisher's (1961) bathymetric map for the northern section of the Middle America Trench (perhaps because of sparser track coverage it is not evident on his Section 3 and Section 6 maps for the central and southern segments). Seabeam bathymetry shows that within the Leg 67 study area a ridge strikes and plunges northwest, crossing the Trench obliquely and intersecting the continental margin near Hole 500 (Aubouin et al., this volume). That horst separates ponds of sediment accumulating in the Trench axis and probably trends beneath the continental margin northwest of Site 500. Peru-Chile Multichannel Line 2 (fig. 5, Kulm et al., 1981) is perhaps an example of a similar feature completely buried beneath the Peruvian margin.
As the block diagram shows, the axial turbidites simply bury the lithology and extensional features common to the entire seaward slope of the Trench (Fig. 12). The present position of the topographic axis of the Middle America Trench therefore results from the outbuilding of the landward slope, a concept that Ludwig et al. (1967) proposed 15 years ago for the Manila Trench. Drilling at Sites 494, 496, 497, and 498 indicates that for Guatemala, outbuilding is manifest in the form of downslope creep of a drape of hemipelagic mud $300+$ meters thick. That mud is probably burying axial turbidites and the underlying basalt and sedimentary overburden of the Cocos Plate. There is no evidence that those turbidites are swept up into a seaward-building inner slope of the Trench.

Drilling at Sites 499 and 500 documented extensional tectonics for the Leg 67 segment of the Middle America Trench axis. The structural cross section (Fig. 6) probably offers an accurate assessment of processes within most trenches, at least within those exhibiting comparable features in the geophysical survey data. A few notable exceptions should be mentioned, however.

Jongsma and Mascle (1981) and Mascle et al. (1982) mapped thrusts along the outer slope of the Hellenic 


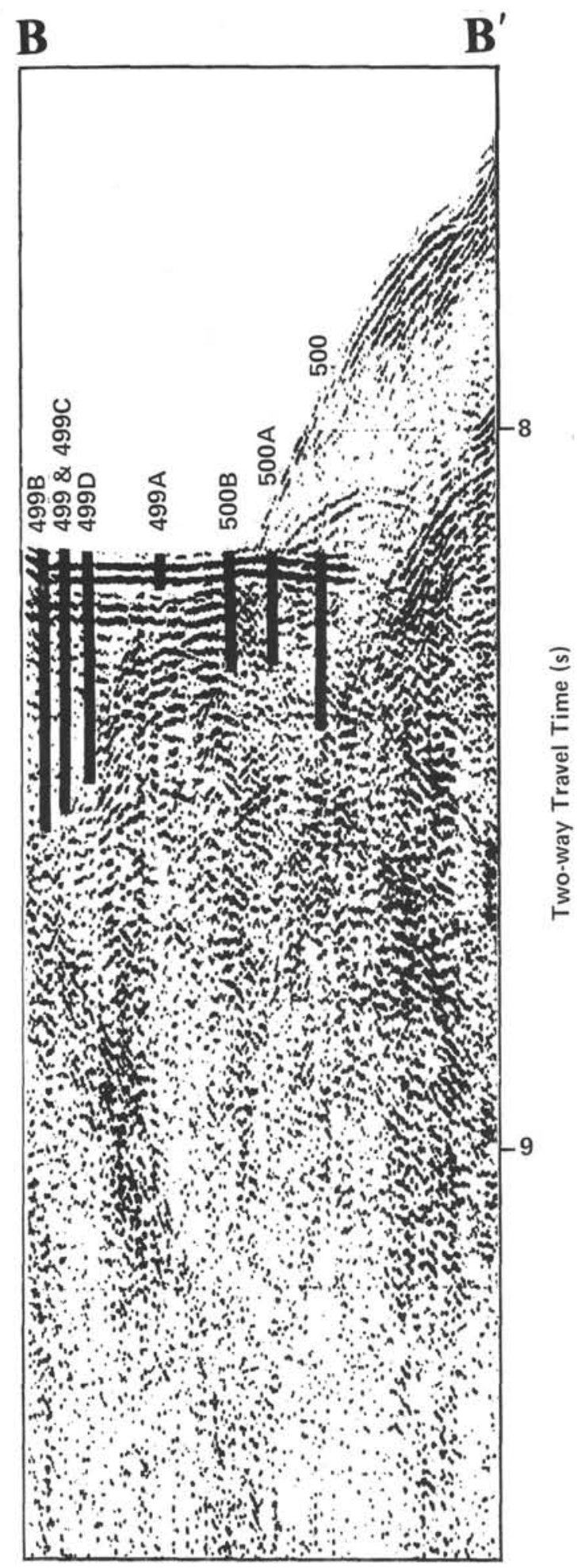

Figure 9. Seismic-reflection profile $\mathrm{BB}^{\prime}$. (Frequency bandwidth is 40 $\mathrm{Hz}-80 \mathrm{~Hz}$. Black vertical lines represent hole locations plotted with respect to Site 499 and 500 beacons. Based on those locations, this profile probably extends farther south than indicated in the navigation plotted in Fig. 2. All holes except 499A penetrated basalt.)

and Matapan trenches, seemingly exceptional cases. Photographs from submersibles clearly support their interpretation (see Ph 1. Plonge H7-42, Dercourt, 1981). Among other possible origins, they attribute the unusu- al configuration shown in their profiles to the mobilization of Messinian evaporites underlying the axial turbidites.

Only a gentle warping (Fig. 3) or small offset (Fig. 4) is visible in the reflections from turbidites filling the Trench axis off Guatemala. Some of the multichannel profiles from the Leg 66 transects of the Middle America Trench also show deformation of Trench-filling sediments at the toe of the landward slope of the margin of southern Mexico (Shipley et al., 1980; Shipley, 1982). In contrast to the progressive burial of turbidites in the Leg 67 study area, the distribution of sands resembling those in the Trench axis led to their use as indicators of uplift and progressive accretion in the Leg 66 study area (Moore et al., 1979). Folds and crumpling of turbidites are seen in profiles perpendicular to the coasts of Oman (White and Klitgord, 1976), Shikoku Island, Japan (Hilde et al., 1969), and Oregon, U.S.A. (Carson et al., 1974). Those features could indicate compression of that fill against the adjacent continental margin but could also represent sediments disturbed by the creep and slump of sediment blanketing the landward slope, as shown in processed multichannel seismic records from the Japan Trench (Matsuzawa et al., 1980).

Published profiles from the Peru Trench near $9^{\circ} \mathrm{S}$ latitude show ridges, interpreted as uplifted thrust blocks, near the base of the seaward slope and within the Trench axis (Kulm et al., 1973a; Prince and Kulm, 1975; Kulm et al., 1981). At several locations along the Peru-Chile Trench, turbidites derived from the continental margin are found seaward and perched above their counterparts filling the Trench axis (Prince et al., 1974; Schweller, 1976; Coulbourn, 1977). Prince et al. (1974) interpreted that sediment distribution as evidence for uplift and thrusting within the Trench axis; Prince and Schweller (1978) computed rates of uplift, but Coulbourn (1981) viewed similar patterns near $19^{\circ} \mathrm{S}$ latitude as a response of sedimentation to oblique subduction. Ridges crossing the Peru-Chile Trench at the Arica Bight appear as crests of Nazca Plate scarps sinking beneath the turbidites accumulating around their flanks. A similar geometry exists along the Middle America Trench (Moore, this volume; Aubouin et al., this volume), and drilling at Sites 499 and 500 indicate that it is a product of extension and burial, not of thrusting and uplift.

\section{CONCLUSIONS}

Sediments drilled at Sites 499 and 500 are not in the process of being swept up into the lower Trench slope. Morphology, stratigraphy, and geophysical information indicate extension of the seaward slope and Trench axis at least to the toe of the landward slope and probably for some distance beneath the Guatemalan margin. Erosion of sediment can occur along ridges of the seaward slope before the entire lithologic sequence founders, first beneath turbidites of the Trench axis, second beneath hemipelagic muds draping the Guatemalan margin. In contrast to the interpretations of geophysical and sedimentological data from the Leg 66 study area off southern Mexico, the Leg 67 surveys and samples do not support the concept of outbuilding of the Guatemalan 


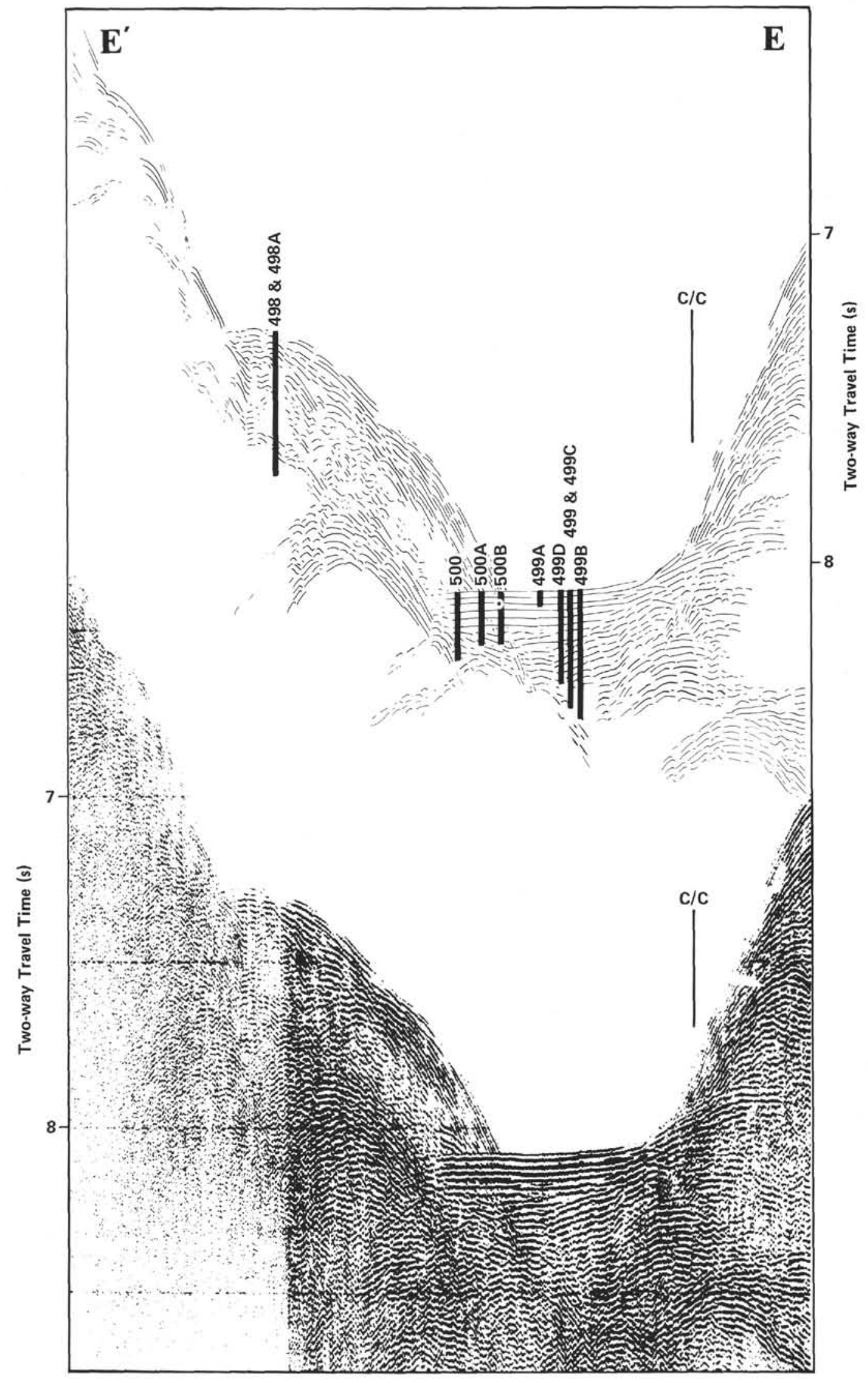

Figure 10. Seismic-reflection profile E'E and its tracing. (Frequency bandwidth is $40 \mathrm{~Hz}-80 \mathrm{~Hz}$; see Fig. 2 for location. Black vertical lines represent orthogonal projection of drill holes onto the plane of the profile. $\mathrm{C} / \mathrm{C}$ indicates course change). 


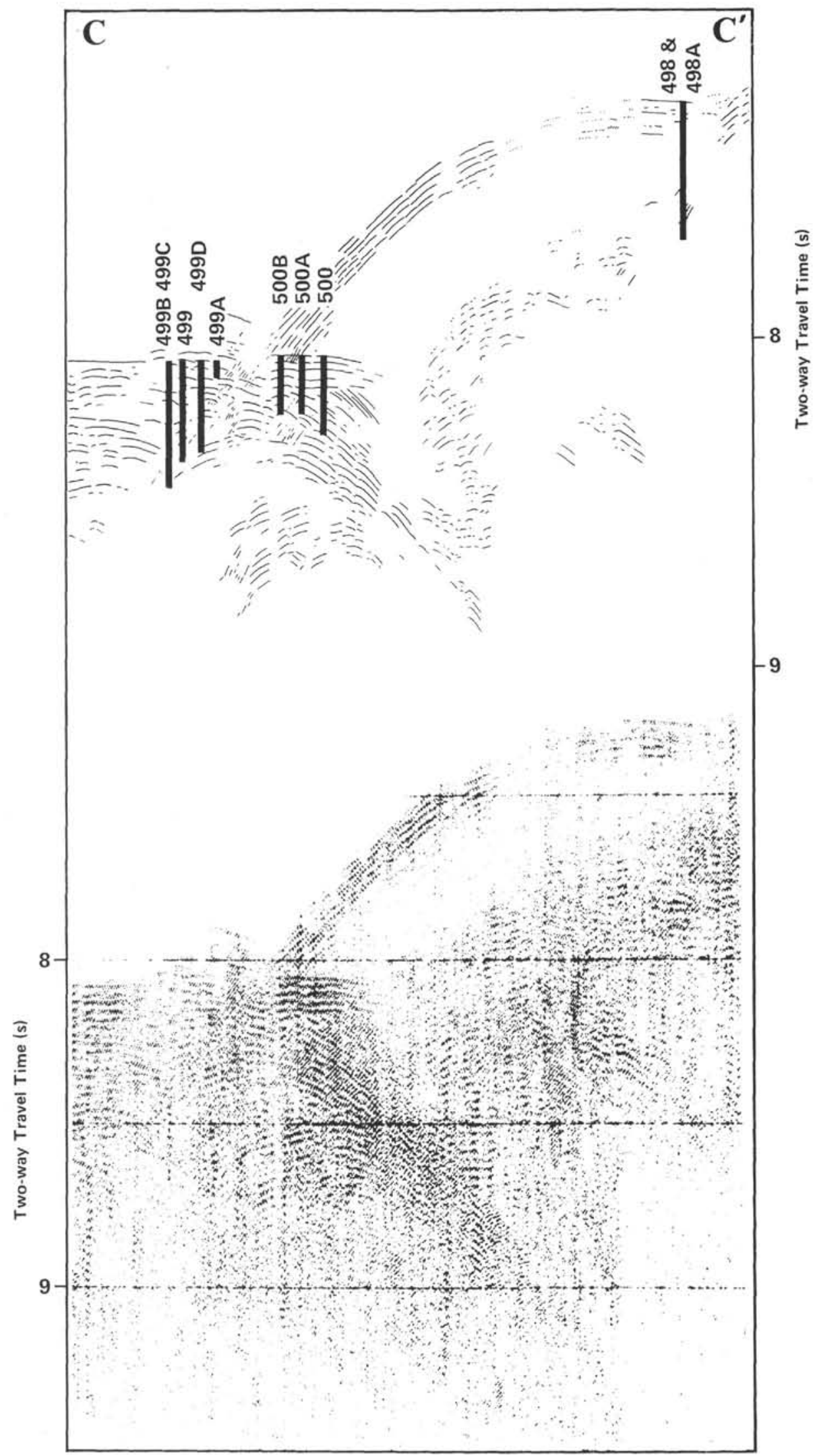

Figure 11. Seismic-reflection profile $\mathrm{CC}^{\prime}$ and its tracing. (Frequency bandwidth is $40 \mathrm{~Hz}-80 \mathrm{~Hz}$; see Fig. 2 for location. Black vertical lines represent along-strike projection of drill holes onto the plane of the profile.) 


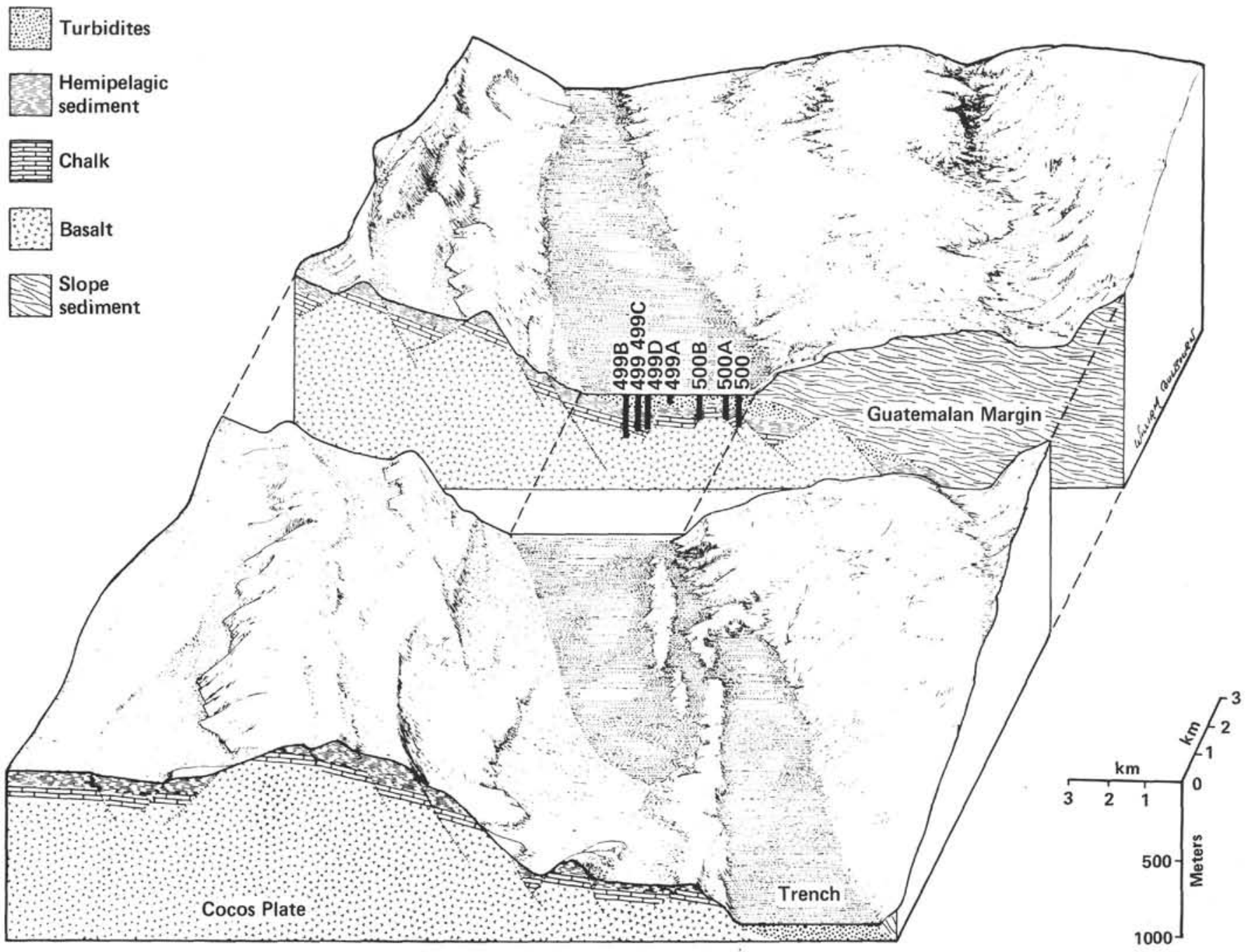

Figure 12. Geologic structure of the Middle America Trench. (Block diagram is constructed from a preliminary version of a Seabeam map of the Leg 67 study area [Aubouin, et al., this volume] and the perspective view is toward the WNW. The cross section is oriented along profile GUA-13 [see Fig. 2]. Tensional features of the Cocos Plate, its pelagic sediment cover, and Trench turbidites are passively buried beneath the blanket of sediment moving downslope under the influence of gravity.)

margin through progressive accretion of axial turbidites, unless that process is occurring at considerable depth beneath the landward slope. Evidently, the Cocos and Caribbean plates are uncoupled at the landward slope, as the Cocos Plate sinks beneath the Guatemalan margin carrying its sedimentary overburden beyond our view.

\section{ACKNOWLEDGMENTS}

John Ladd provided a copy of seismic profile GUA-13 and Jean Aubouin supplied a preliminary version of the Seabeam map from which Figure 12 was drawn. Barbara Long sorted out the navigation records, making a reasonable plot of the hole locations at Sites 499 and 500 possible. Thanks also go to Greg Moore and Ralph Moberly for reviewing the manuscript and to Roland von Huene and Dave Moore for the opportunity to participate in Leg 67 of the Deep Sea Drilling Project.

\section{REFERENCES}

Bellaiche, G., 1967. Résultats d'une étude géologique de la fosse du Japon effectuée en bathyscaphe "Archimède." C. R. Hebd. Seances Acad. Sci., 265:1160-1163.
1980. Sedimentation and structure of the Izu-Ogasawara (Basin) Trench off Tokyo: new lights on the results of a diving campaign with the bathyscaph "Archimède." Earth Planet. Sci. Lett., 47:124-130.

Benioff, H., 1954. Orogenesis and deep crustal structure: additional evidence from seismology. Geol. Soc. Am. Bull., 65:385-400.

Berger, W. H., and Winterer, E. L., 1974. Plate stratigraphy and the fluctuating carbonate line. In Hsú, K. J., and Jenkyns, H. C. (Eds.), Pelagic Sediments: On Land and Under the Sea: Oxford (Blackwell Scientific Pubs.), pp. 11-48.

Caldwell, J. G., Haxby, W. F., Karig, D. E., and Turcotte, D. L., 1976. On the applicability of a universal elastic trench profile. Earth Planet. Sci. Lett., 31:239-246.

Carson, B., Yuan, J., Myers, P. B., and Barnard, W. D., 1974. Initial deep sea sediment deformation at the base of the Washington continental slope: a response to subduction. Geology, 2:561-564.

Chase, R. L., and Bunce, E. T., 1969. Underthrusting of the eastern margin of the Antilles by the floor of the western North Atlantic Ocean, and origin of the Barbados Ridge. J. Geophys. Res., 74: 1413-1420.

Connolly, J., and Ewing, M., 1967. Sedimentation in the Puerto Rico Trench. J. Sediment. Petrol., 37:44-59.

Coulbourn, W. T., 1977. Tectonics and sediments of the Peru-Chile Trench and continental margin at the Arica Bight. [Ph.D. dissert.]. University of Hawaii, Honolulu. 
1980. Relationship between the distribution of foraminifera and geologic structures of the Arica Bight, South America. J. Paleontol., 54:696-718.

1981. Tectonics of the Nazca Plate and the continental margin of western South America, $18^{\circ} \mathrm{S}$ to $23^{\circ} \mathrm{S}$. In Kulm, L. D., Dymond, J., et al. (Eds.), Nazca Plate: Crustal Formation and Andean Convergence: Ann Arbor (Geol. Soc. Am. Mem. 154), pp. 587-618.

Coulbourn, W. T., and Moberly, R., 1977. Structural evidence of the evolution of fore-arc basins off South America. Can. J. Earth Sci., 14:102-116.

Coulbourn, W. T., and Resig, J. M., 1979. Middle Eocene pelagic microfossils from the Nazca Plate. Geol. Soc. Am. Bull., 90: 643-650.

Dean, B. W., and Drake, C. L., 1978. Focal mechanism solutions and tectonics of the Middle America Arc. J. Geol., 86:111-128.

Dercourt, J., 1981. Programme HEAT Campagne Submersible Les Fossés Helléniques: Brest (Centre Oceanologique de Bretagne).

Dietz, R. S., 1961. Continent and ocean basin evolution by spreading of the seafloor. Nature, 190:854-857.

Elsasser, W. M., 1968. Submarine trenches and deformation. Science, 160:1024.

Ewing, M., Lonardi, A. G., and Ewing, J. I., 1965. The sediments and topography of the Puerto Rico Trench and outer ridge. Fourth Caribbean Geol. Conf., Trinidad, pp. 325-334.

Fisher, R. L., 1961. Middle America Trench: topography and structure. Geol. Soc. Am. Bull., 72:703-720.

Hanks, T. C., 1971. The Kuril-Hokkaido trench system: large shallow earthquakes and simple models of deformation. Geophys, J. R. Astron. Soc., 23:173-189.

Hilde, T. W. C., Wageman, J. M., and Hammond, W. T., 1969. The structure of Tosa Terrace and Nankai Trough off southeastern Japan. Deep-Sea Res., 16:67-75.

Honza, E., 1980. Pre-site survey of the Japan Trench transect, Deep Sea Drilling Project. In Scientific Party, Init. Repts. DSDP, 56, 57, Pt. 2: Washington (U.S. Govt. Printing Office), 449-458.

Isacks, B., and Molnar, P., 1969. Mantle earthquake mechanisms and the sinking of the lithosphere. Nature, 223:1121-1124.

Isacks, B., Oliver, J., and Sykes, L. R., 1968. Seismology and the new global tectonics. J. Geophys. Res., 73:5855-5899.

Jongsma, D., and Mascle, J., 1981. Evidence for northward thrusting south-west of the Rhodes Basin. Nature, 293:49-51.

Jordan, T. H., 1975. the Present-day motions of the Caribbean Plate. J. Geophys. Res., 80:4433-4439.

Karig, D. E., Cardwell, R. K., Moore, G. F., and Moore, D. G., 1978. Late Cenozoic subduction and continental margin truncation along the northern Middle America Trench. Geol. Soc. Am. Bull., 89: 265-276.

Kulm, L. D., Prince, R. A., French, W., Johnson, S., and Masias, A., 1981. Crustal structure and tectonics of the central Peru continental margin and trench. In Kulm, L. D., Dymond, J., et al. (Eds.), Nazca Plate: Crustal Formation and Andean Convergence: Ann Arbor (Geol. Soc. Am. Mem. 154), pp. 445-468.

Kulm, L. D., Scheidegger, K. F., Prince, R. A., Dymond, J., Moore, T. C., and Hussong, D. M., 1973a. Tholeiitic basalt ridge in the Peru Trench. Geology, 1:11-14.

Kulm, L. D., von Huene, R., Duncan, J. R., Ingle, J. C., Kling, S. A., Musich, L. F., Piper, D. J. W., Pratt, R. M., Schrader, H.-J., Weser, O., and Wise, S. W., 1973b. Sites 174 and 180. In Kulm, L. D., von Huene, R., et al., Init. Repts DSDP, 18: Washington (U.S. Govt. Printing Office), 97-167, 407-447.

Lister, R. L., 1969. Tectonic movement in the Chile Trench. Science, 173:719-722

Ludwig, W. J., Hayes, D. E., and Ewing, J. I., 1967. The Manila Trench and West Luzon Trough. I. Bathymetry and sediment distribution. Deep-Sea Res., 14:533-544.

Mascle, J., Le Quellec, P., Leite, O., and Jongsma, D., 1982. Structural sketch of the Hellenic continental margin between the western Peloponnesus and eastern Crete. Geology, 10:113-116.

Matsuzawa, A., Tamano, T., Aoki, Y., and Ikawa, T., 1980. Structure of the Japan Trench subduction zone, from multichannel seismicreflection records. Mar. Geol., 35:171-182.

Minster, J. B., and Jordan, T. H., 1978. Present-day plate motions. J. Geophys. Res., 83:5331-5354.
Molnar, P., and Sykes, L. R., 1969. Tectonics of the Caribbean and Middle America regions from focal mechanisms and seismicity. Geol. Soc. Am. Bull., 80:1639-1684.

Montecchi, P. A., 1976. Some shallow tectonic consequences of subduction and their meaning to the hydrocarbon explorationist. In Halbouty, M. T., et al. (Eds.), Circum-Pacific Energy and Mineral Resources: Tulsa (Am. Assoc. Petrol. Geol. Mem. 25), pp. 189-202.

Moore, G. F., and Curray, J. R., 1981. Structure of the Sunda Trench lower slope off Sumatra from multichannel seismic reflection data. Mar. Geophys. Res., 4:319-340.

Moore, J. C., Watkins, J. S., Shipley, T. H., Bachman, S. B., Beghtel, F. W., Butt, A., Didyk, B. M., Leggett, J. K., Lundberg, N., McMillen, K. J., Niitsuma, N., Shephard, L. E., Stephan, J.-F., and Stradner, H., 1979. Progressive accretion in the Middle America Trench, southern Mexico. Nature, 281:638-642.

Morgan, W. J., 1968. Rises, trenches, great faults, and crustal blocks. J. Geophys. Res., 73:1959-1982.

Piper, D. J. W., Von Huene, R., and Duncan, J. R., 1973. Late Quaternary sedimentation in the active eastern Aleutian Trench. Geology, 1:19-22.

Prince, R. A., and Kulm, L. D., 1975. Crustal rupture and the initiation of imbricate thrusting in the Peru-Chile Trench. Geol. Soc. Am. Bull., 86:1639-1653.

Prince, R. A., Resig, J. M., Kulm, L. D., and Moore, T. C., Jr., 1974. Uplifted turbidite basins on the seaward wall of the Peru Trench. Geology, 2:607-611.

Prince, R. A., and Schweller, W. J., 1978. Dates, rates and angles of faulting in the Peru-Chile Trench. Nature, 271:743-745.

Resig, J. M., 1981. Biogeography of benthic foraminifera of the northern Nazca Plate and adjacent margin. In Kulm, L. D., Dymond, J., et al. (Eds.), Nazca Plate: Crustal Formation and Andean Convergence: Ann Arbor (Geol. Soc. Am. Mem. 154), pp. 619-666.

Rona, P. A., Harbinson, R. N., Bassinger, B. G., Scott, R. B., and Nalwalk, A. J., 1976. Tectonic fabric and hydrothermal activity of Mid-Atlantic Ridge Crest (Lat. $26^{\circ} \mathrm{N}$ ). Geol. Soc. Am. Bull., 87: 661-674.

Ross, D. A., 1971. Sediments of the northern Middle America Trench. Geol. Soc. Am. Bull., 82:303-322.

Ross, D. A., and Shor, G. G., 1965. Reflection profiles across the Middle America Trench. J. Geophys. Res., 70:5551-5572.

Ryan, W. B. F., Hsü, K. J., Cita, M. B., Dumitriča, P, Lort, J., Mayne, W., Nesteroff, W. D., Pautot, G., Stradner, H., and Wezel, F. C., 1973. Hellenic Trench-Sites 127 and 128. In Ryan, W. B. F., Hsü, K. J., et al., Init. Reports DSDP, 13, Pt. 1: Washington (U.S. Govt. Printing Office), 242-278.

Scholl, D. W., von Huene, R., and Ridlon, J. B., 1968. Spreading of the ocean floor: undeformed sediments in the Peru-Chile Trench. Science, 159:869.

Schweller, W. J., 1976. Chile Trench: Extensional rupture of oceanic crust and the influence of tectonics on sediment distribution [M.S. thesis]. Oregon State University, Corvallis.

Seely, D. R., Vail, P. R., and Walton, G. G., 1974. Trench-slope model. In Burk, C. A., and Drake, C. L. (Eds.), The Geology of Continental Margins: New York (Springer-Verlag), pp. 249-260.

Seyfert, C. K., 1969. Undeformed sediments in oceanic trenches with seafloor spreading. Nature, 222:70.

Shepherd, G. L., and Moberly, R., 1981. Coastal structure of the continental margin, northwest Peru and southwest Ecuador. In Kulm, L. D., Dymond, J., et al. (Eds.), Nazca Plate: Crustal Formation and Andean Convergence: Ann Arbor (Geol. Soc. Am. Mem. 154), pp. 351-391.

Shipley, T. H., 1982. Seismic facies and structural framework of the southern Mexico continental margin. In Watkins, J. S., Moore, J. C., et al., Init. Repts. DSDP, 66: Washington (U.S. Govt. Printing Office), 775-790.

Shipley, T. H., McMillen, K. J., Watkins, J. S., Moore, J. C., Sandoval-Ochoa, J. H., and Worzel, J. L., 1980. Continental margin and lower slope structures of the Middle America Trench near Acapulco.(Mexico). Mar. Geol., 35:65-82.

von Huene, R., 1972. Structure of the continental margin and tectonism at the eastern Aleutian Trench. Geol. Soc. Am. Bull., $83: 3613-3626$. 


\section{W. T. COULBOURN}

von Huene, R., Aubouin, J., et al., 1980. Leg 67: The Deep Sea Drilling Project Mid-America Trench transect off Guatemala. Geol. Soc. Am. Bull., 91, Pt. 1: 421-432.

von Huene, R., Scholl, D. W., and Ridlon, J. B., 1968a. Spreading of the ocean floor: undeformed sediments in the Peru-Chile Trench. Science, 159:869.

1024
Watkins, J. S., Moore, J. C., Bachman, S. B., Beghtel, F. W., Butt, A., Didyk, B. M., Foss, G., Leggett, J. K., Lundberg, N., McMillen, K. J., Niitsuma, N., Shephard, L. E., Stephan, J.-F., Shipley, T. H., and Stradner, H., 1982. Site 486. In Watkins, J. S., Moore, J. C., et al., Init. Repts. DSDP, 66: Washington (U.S. Govt. Printing Office), 19-30.

White, R. S., and Klitgord, K., 1976. Sediment deformation and plate tectonics in the Gulf of Oman. Earth Planet. Sci. Lett., 32:199-209. 